ЭКОНОМИЧЕСКИЕ НАУКИ

\title{
FORECASTING THE EXPORT VOLUME OF THE KYZYLORDA REGION OF
} THE REPUBLIC OF KAZAKHSTAN

\author{
DOI: 10.31618/ESU.2413-9335.2021.1.90.1451 \\ Aralbayeva G.G., \\ Federal State Budgetary Educational Institution \\ of Higher Education «Orenburg State University», \\ Orenburg, Russia \\ Berikbolova U.D., \\ Master of Economics, \\ Senior Lecturer, Korkyt Ata Kyzylorda University, \\ Kyzylorda, Kazakhstan
}

\section{ПРОГНОЗИРОВАНИЕ ОБЪЕМА ЭКСПОРТА КЫЗЫЛОРДИНСКОЙ ОБЛАСТИ РЕСПУБЛИКИ КАЗАХСТАН}

\author{
Аралбаева Г.Г. \\ ФГБОУ «Оренбургский государственный университет», \\ 2. Оренбург, Россия \\ Берикболова У.Д. \\ магистр экономических наук, старший преподаватель, \\ Кызылординский государственный университет имени Коркыт Ата, \\ Казахстан
}

\begin{abstract}
The article presents the results of forecasting the export of the Kyzylorda region of the Republic of Kazakhstan. According to the article the export data of the Kyzylorda region of the Republic of Kazakhstan are characterized by an unstable trend. According to the article, since 2014 the region has experienced an annual decline in export volumes which is associated with a decrease in oil production due to the exhaustion of resources, as well as a drop in uranium production which is associated with the price situation. It is emphasized that at the same time, industrial production is being reoriented to other types of economic activities related to innovation, in particular, the export of ammonium metavanadate and other products started in 2016. It is stated that the forecast of export volume showed an increase in export volumes in the following years, due to an increase in investment in innovative products. The dynamics of investments in innovations in the Kyzylorda region is considered, a model is built and a forecast of the volume of investments in innovations is made.

\section{АННОТАЦИЯ}

В статье представлены результаты прогнозирования экспорта Кызылординской области Республики Казахстан. Данные экспорта Кызылординской области Республики Казахстан характеризуются нестабильным трендом. С 2014 года в регионе отмечается ежегодное снижение объемов экспорта, что связано с уменьшением добычи нефти в связи с исчерпанием ресурсов, а также падением добычи урана, что связано с ценовой конъюнктурой. Одновременно происходит переориентация промышленного производства на другие виды экономической деятельности, связанные с инновационной, в частности, с 2016 года начался экспорт метаванадат аммония и другой продукции. Прогноз объема экспорта показал увеличение объемов экспорта в последующие годы, обусловленный увеличением объема инвестиций в инновационные продукты. Рассмотрена динамика инвестиций в инновации в Кызылординской области, построена модель и произведен прогноз объема инвестиций в инновации.
\end{abstract}

Keywords: innovation, export, investment, region, forecast, forecasting.

Ключевые слова: инновации, экспорт, инвестиции, регион, прогноз, прогнозирование.

Kazakhstan is a state that is already sufficiently integrated into the world economy. The dependence of the national economy on exports reflects the state of the economy of Kazakhstan which is likely to continue in the coming decades. The path of economic development of the republic mainly corresponds to the trends in the development of the world economy. Raw materials are the most important component of exports. The transition of Kazakhstan's regions to non-primary exports is important for the further development of the country's economy. This is possible only as a result of the transition of the Republic of Kazakhstan and its regions to a resource-innovative model of economic development.

The forecast of the export of the Kyzylorda region was made on the basis of mathematical models with the inclusion of the autoregressive part. The Gretl package was used for the analysis. The parameters were estimated using the maximum likelihood method.

Kazakhstan's exports of goods have a rather unstable dynamics. It reached its peak in 2012 of $\$ 86.4$ bln US dollars. In 2016 the volume of exports fell below the level of 2007. According to the results of 
2016, the export of goods of the Republic of Kazakhstan amounted to 36.8 bln US dollars.

Figure 1 shows the dynamics of exports of the Kyzylorda region for the period from 2000 to 2019 (data for 2020 was not available at the time of calculations) $[1,2]$.

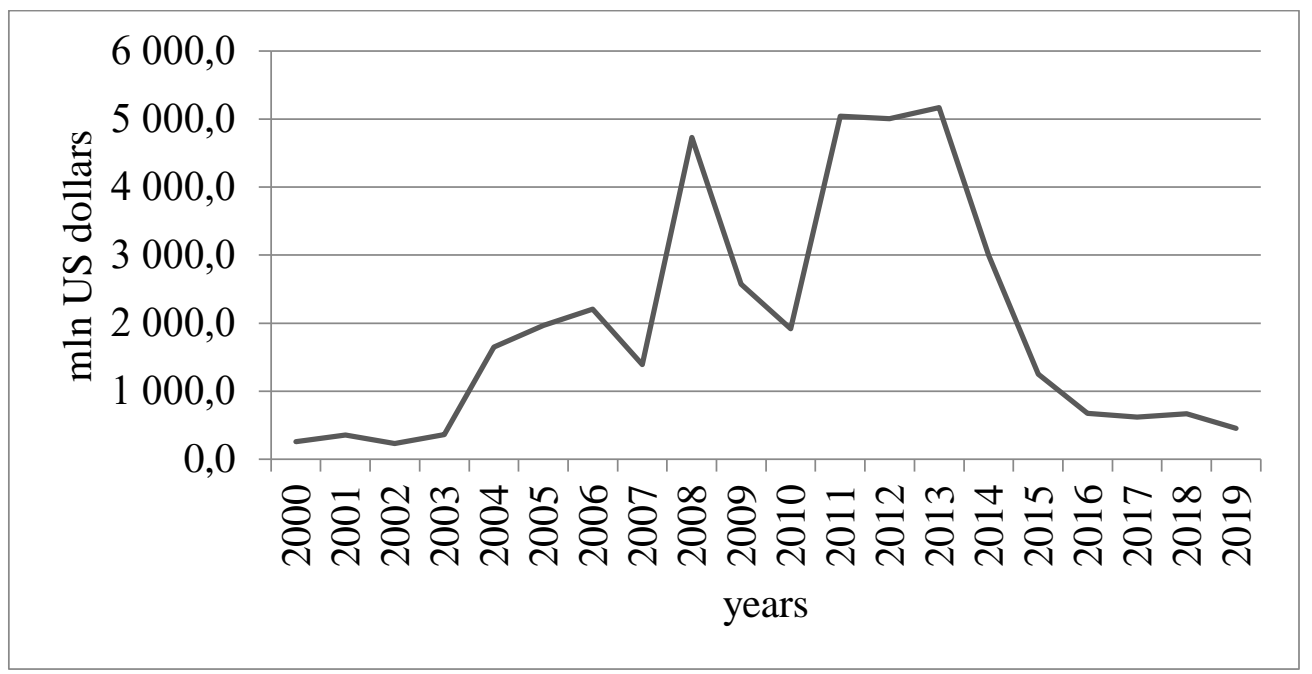

Figure 1. Dynamics of export of the Kyzylorda region of the Republic of Kazakhstan for 2000-2019

In the dynamics of exports of the Kyzylorda region a number of periods can be distinguished characterized by growth, decline and relative stability. The global economic crisis of 2008-2009 led to a drop in the region's exports by almost 2.5 times in 2010 compared to 2008. Since 2014 there has been an annual decline in export volumes in the region which is associated with a decrease in oil production due to the exhaustion of resources, as well as a drop in the production of a number of resources due to changes in the price environment. At the same time industrial production is being reoriented to other types of economic activity. In particular, exports of the fishing industry, salt, cement, propane-butane are growing, and export of ammonium metavanadate has begun in 2016 [1].

In $2019,90 \%$ of the exported products were end products including products created using the latest technologies. Such results appeared due to the growth of investment in innovations. For example, in 2016 compared to 2013, there was more than a sevenfold increase in investment in innovations. In 2018 compared to 2016, the growth was 1.7 times.

The export forecast of the Kyzylorda region was carried out on the basis of mathematical models with the inclusion of the autoregressive part, and previous and possible crisis phenomena were also taken into account using a dichotomous variable that takes the value 0 in periods of growth and stability, and takes the value 1 in crisis periods [3]. It should be noted that when forecasting, the dichotomous variable for 2020 is assigned at level 1 which follows from the situation related to the spread of COVID-19. In subsequent forecast periods the dichotomous variable will take the value 0 expecting an improvement in the situation in 2021-2023.

General view of the model:

$$
\operatorname{Exp}_{t}=\alpha_{0}+\alpha_{1} \operatorname{Exp}_{t-1}+\varepsilon_{t}+\beta_{1} \varepsilon_{t-1}+\gamma K_{t},
$$

where $\operatorname{Exp}_{\mathrm{t}}$ - the volume of exports of the Kyzylorda region at a time $\mathrm{t}, \mathrm{t}=1, \ldots, 20$;

$\alpha_{0}$ - free parameter;

$\alpha_{1}$ - coefficient for first-order autoregression;

$\beta_{1}$ - moving average parameter;

$\gamma$ - parameter for a dichotomous variable $\mathrm{K}_{\mathrm{t}}$;

$\varepsilon_{t^{-}}$white noise (a stationary random (nonautocorrelated) process distributed according to a normal law with zero mathematical expectation and constant variance).

The evaluation results are presented in table 1.

Table 1.

Results of evaluation of the export forecasting model of the Kyzylorda region

\begin{tabular}{|c|c|c|c|}
\hline $\begin{array}{l}\text { Parameter } \\
\text { name }\end{array}$ & $\begin{array}{l}\text { Parameter } \\
\text { estimation }\end{array}$ & $\begin{array}{l}\text { Standard } \\
\text { deviation }\end{array}$ & $\mathrm{p}$ - value (significance) \\
\hline$\alpha_{0}$ & 2465,19 & 926,88 & $\begin{array}{c}0,0078 \text { (significant at a } 0,01 \text { significance } \\
\text { level) }\end{array}$ \\
\hline$\alpha_{1}$ & 0,74 & 0,14 & $\begin{array}{c}0,0000 \text { (significant at a } 0,01 \text { significance } \\
\text { level) }\end{array}$ \\
\hline$\beta_{1}$ & 0,99 & 0,21 & $\begin{array}{c}0,0000 \text { (significant at a } 0,01 \text { significance } \\
\text { level) }\end{array}$ \\
\hline$\gamma$ & $-1998,25$ & 157,92 & $\begin{array}{c}0,0000 \text { (significant at a } 0,01 \text { significance } \\
\text { level) }\end{array}$ \\
\hline
\end{tabular}


The obtained model is adequate to the sample data (confirmed by the results of calculations). Table 2 shows the results of forecasting under various scenarios of the situation development which we described on the basis of a dichotomous variable. According to the first scenario, the Kyzylorda region will experience crisis phenomena only in 2020 and in subsequent years the situation will be considered as favorable (the dichotomous variable takes the values 0 ) (the result of the forecast can be checked when export data are published in statistical collections).

Results of forecasting according to the model (1)

\begin{tabular}{|c|c|c|c|c|}
\hline $\begin{array}{c}\text { Forecast } \\
\text { period }\end{array}$ & $\begin{array}{c}\text { The value of the } \\
\text { dichotomous variable } \\
\text { (1 scenario) }\end{array}$ & $\begin{array}{c}\text { Export forecast, } \\
\text { mln. US dollars }\end{array}$ & $\begin{array}{c}\text { The value of the } \\
\text { dichotomous variable }\end{array}$ & $\begin{array}{c}\text { Export forecast, mln. } \\
\text { US dollars } \\
(2 \text { scenario })\end{array}$ \\
\hline 2020 & 1 & 157,0 & 1 & 157,0 \\
\hline 2021 & 0 & 2234,8 & 1 & 236,6 \\
\hline 2022 & 0 & 2294,0 & 1 & 295,7 \\
\hline 2023 & 0 & 2338,0 & 1 & 339,7 \\
\hline
\end{tabular}

According to the second scenario, after 2020 negative crisis phenomena will also be observed in the dynamics of exports, the dichotomous variable takes the value 1 .

Despite the fact that only two variants of the situation are described here, the forecast can be also recalculated by making changes to the dichotomous variable. For example, at the end of 2020 the first assumptions about the change in the situation can be made and, accordingly, the forecast can be refined.

According to the assessment of model (1), for both scenarios it is expected that in 2020 the lowest values of exports over the last decade will be observed. In addition, in both cases export growth is expected in the future. If negative trends persist (according to the second scenario), by 2023 exports in the Kyzylorda region will amount to $\$ 339.7$ million which will be carried out through the development of the manufacturing industry, the introduction of innovations in various fields of activity.

According to the first scenario, by the end of the forecast period exports are expected to grow to $\$ 2,338$ million which is possible if there are positive changes, in particular, the growth of uranium exports, the growth of production of competitive innovative developments.

On the basis of the developed mathematical model, the subsequent growth of exports of the Kyzylorda region in the conditions of crisis phenomena can be proved. The dynamics of investment in innovations in the Kyzylorda region should be considered. A number of studies have shown that an integrated moving average autoregression model with one autoregression order and one moving average order should be evaluated:

$$
\Delta \text { InvInnov }_{t}=\alpha_{1} \Delta \text { InvInnov }_{t-1}+\varepsilon_{t}+\beta_{1} \varepsilon_{t-1},
$$

where $\Delta I n v I n n o v_{t \mathrm{t}}-$ an increase in the volume of investments in innovations of the Kyzylorda region at a time $\mathrm{t}, \mathrm{t}=1, \ldots, 20$;

$\alpha_{1}$ - coefficient for first-order autoregression;

$\beta_{1}$ - moving average parameter;

$\varepsilon_{t^{-}}$white noise (a stationary random (nonautocorrelated) process distributed according to a normal law with zero mathematical expectation and constant variance).

The variables reflecting the crisis phenomena were not introduced into the model (2) which is due to the fact that by its nature investment in innovations is an exogenous indicator, that is, to a certain extent it is a controlled factor including on the part of the state. In this situation it is justified to choose a model based on its previous values, that is, in other words, on the vector of innovation development adopted by the authorities.

The Gretl package was used for the analysis, the parameters were estimated using the maximum likelihood method [3]. The evaluation results are presented in table 3 .

Table 3.

Results of evaluation of the investment forecasting model in innovations of the Kyzylorda region

\begin{tabular}{|c|c|c|c|}
\hline $\begin{array}{l}\text { Parameter } \\
\text { name }\end{array}$ & $\begin{array}{l}\text { Parameter } \\
\text { estimation }\end{array}$ & $\begin{array}{l}\text { Standard } \\
\text { deviation }\end{array}$ & $\mathrm{p}$ - value (significance) \\
\hline$\alpha_{1}$ & 0,67 & 0,18 & $\begin{array}{c}0,0004 \text { (significant at a } 0,01 \text { significance } \\
\text { level) }\end{array}$ \\
\hline$\beta_{1}$ & $-0,99$ & 0,32 & $\begin{array}{c}0,0022 \text { (significant at a } 0,01 \text { significance } \\
\text { level) }\end{array}$ \\
\hline
\end{tabular}

The resulting model is adequate to the sample data presented by statistical data. Table 4 shows the results of forecasting investments in innovations in the Kyzylorda region. 
Table 4.

Results of forecasting investments in innovations according to the model (2)

\begin{tabular}{|c|c|c|c|}
\hline $\begin{array}{c}\text { Forecast } \\
\text { period }\end{array}$ & $\begin{array}{c}\text { Forecast of investment in } \\
\text { innovations, } \\
\text { mln. } \mathbf{T}\end{array}$ & $\begin{array}{c}\text { Lower bound of the } \\
\text { forecast }\end{array}$ & $\begin{array}{c}\text { Upper bound of the } \\
\text { forecast }\end{array}$ \\
\hline 2020 & 8381,2 & 1546,2 & 31849,5 \\
\hline 2021 & 9482,2 & 1786,5 & 37773,6 \\
\hline 2022 & 10224,3 & 2098,9 & 40448,4 \\
\hline 2023 & 10723,6 & 2013,2 & 41784,3 \\
\hline
\end{tabular}

It should be noted that the forecast presented in table 4 is quite "cautious" and assumes a slight increase, although the upper limit of the confidence interval indicates that by 2023 investment in innovations in the region can reach 41784.3 million tenge.

The decline in oil production has led to negative consequences not only in the region's exports but also in the gross regional product. For several years the region had the worst indicators in the republic [2].

The results obtained:

1)The export of the Kyzylorda region decreased during the period under review. At the same time significant efforts have been made in the region over the past decade to develop innovative activities which have resulted in a significant increase in investment in innovations, especially in 2016-2018.

2)The results of export forecasting of the Kyzylorda region of the Republic of Kazakhstan are presented. The export volume forecast showed an increase in export volumes in the following years (2020-2024) due to an increase in investment in innovative products. The results of forecasting under various scenarios of the situation development described on the basis of a dichotomous variable are presented.

3)The dynamics of investments in innovations in the Kyzylorda region is considered, a model is constructed and a forecast of the volume of investments in innovations is made, a further increase in the volume of investments in innovative products is shown.

\section{References}

1.Itogi social'no-jekonomicheskogo razvitija Kyzylordinskoj oblasti v 2019 godu. [The results of the socio-economic development of the Kyzylorda region in 2019] Rezhim dostupa [Available from]: https://kzvesti.kz/kv/frontpage/45070-itogi-socialnoekonomicheskogo-razvitiya-kyzylordinskoy-oblasti-v2019-godu.html. (In Russ).

2.Kazakhstan Respublikasy Strategiyalyk zhosparlau zhyane reformalar agenttigi ulttyk statistika byurosy. [Agency for Strategic planning and reforms of the Republic of Kazakhstan Bureau of National statistics] Rezhim dostupa [Available from]: https://stat.gov.kz/official/industry/11/statistic/6. (In Kazakh).

3.Polovnikov D.S., Kolpakov, I.Ju. Prilozhenija modeli avtoregressii $i$ prointegrirovannogo skol'zjashhego srednego (ARPSS) v jekonomicheskih processah [Applications of the autoregression model and the integrated moving average (ARPSS) in economic processes] № 7. Fundamental'nye issledovanija [Fundamental Research]; 2020. p. 90-95. (In Russ).

4.Semenova V.P. Primenenie programmnogo produkta GRETL v statisticheskih issledovanijah. [Application of the GRETL software product in statistical research] № 2. Sinergija Nauk [Synergy of Sciences]; 2016. p. 56-77. (In Russ).

SOCIO-ECONOMIC DEVELOPMENT INDICATORS OF THE FEDERAL REPUBLIC OF NIGERIA DOI: 10.31618/ESU.2413-9335.2021.1.90.1447

Aigbedion Elvis Osaze

Master's student of the Department of Economic Theory EI "Grodno State Agrarian University»

Hanchar Andrei I.

Head of the Department Economic Theory EI "Grodno State Agrarian University» Grodno, Belarus

The article analyses Nigeria's socio-economic performance. The main attention is paid to the influence of natural and geopolitical conditions on the development of the country's economy. At the same time, the researchers' attention is focused on the health situation, energy development, the number and composition of Nigeria's population, and the reasons for population migration.

Keywords: Africa, Nigeria, development, socio-economic, GDP, inflation, unemployment, imports, exports.

Nigeria is a country in West Africa at the Gulf of Guinea. The land has a total area of $923,770 \mathrm{~km}^{2}$ $\left(356,669 \mathrm{mi}^{2}\right)$ and a total coastline of $853 \mathrm{~km}(530.0$ $\mathrm{mi})$. This land area is approximately $133 \%$ of the area of Texas. Nigeria is thus one of the largest countries in Africa and the 32nd biggest in the world. It is comparatively low at an average elevation of 380 